\title{
Polycomb Complex Protein BMI-1
}

National Cancer Institute

\section{Source}

National Cancer Institute. Polycomb Complex Protein BMI-1. NCI Thesaurus. Code C17480.

Polycomb complex protein BMI-1 (326 aa, $~ 37 \mathrm{kDa}$ ) is encoded by the human BMI1 gene. This protein is involved in transcriptional repression during embryonic development. 